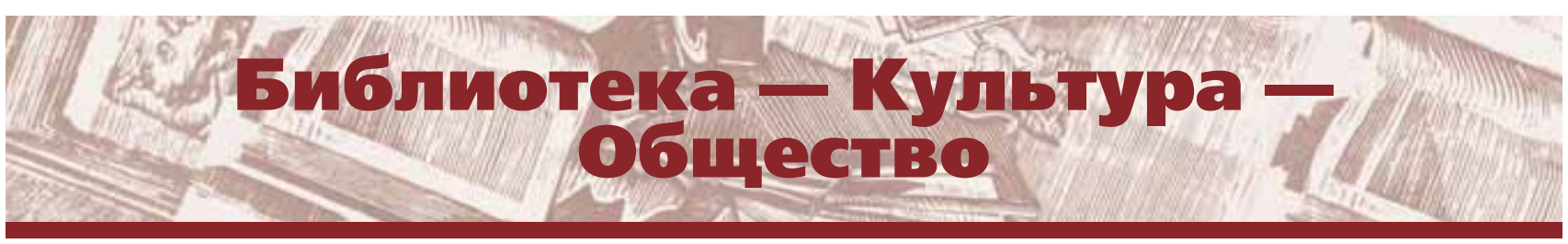

УДК 021(470+575)(063)

ББК 78.34(2Рос)л0

DOI 10.25281/0869-608X-2018-67-3-247-256

\title{
И.А. Трушина, В.В. Мещерякова
}

\section{Всероссийский библиотечный конгресс - 2018: на пути к созданию Концепции развития библиотечного дела}

Реферат. Представлен аналитический обзор мероприятий Всероссийского библиотечного конгресса, состоявшегося 12-18 мая 2018 г. во Владимире - Библиотечной столице России 2018 года - и посвященного теме «Опираясь на прошлое, строим будущее. Роль культурного наследия в преобразовании библиотечного дела России». В ходе Конгресса было проведено открытое обсуждение разработки Концепции развития библиотечного дела в Российской Федерации, принято Руководство по краеведческой деятельности общедоступных (публичных) библиотек РФ, утверждено Положение о Совете по профессиональным квалификациям в области библиотечно-информационной деятельности, который планируется создать при Российской библиотечной ассоциации. Работа Конгресса проходила в различных форматах: предсессионные мероприятия, пленарные заседания, заседания секций по видам библиотек и направлениям деятельности, специальные мероприятия. Сопровождала Конгресс XIX Выставка издательской продукции, новых информационных технологий, товаров и услуг. Определена Библиотечная столица России 2019 г. — город Тула.

Ключевые слова: Российская библиотечная ассоциация, РБА, Всероссийский библиотечный конгресс, Ежегодная конференция РБА, Библиотечная столица России, Концепция развития библиотечного дела, государственная библиотечная политика, библиотеки Владимирской области, библиотекарь года, библиотечное образование.

Для цитирования: Трушина И.А., Мещерякова В.В. Всероссийский библиотечный конгресс - 2018: на пути к созданию Концепции развития библиотечного дела // Библиотековедение. 2018. Т. 67, № 3. C. 247-256. DOI: 10.25281/0869-608X-2018-67-3-247-256.

$\mathrm{B}$ сероссийский библиотечный конгресс: XXIII Ежегодная конференция Российской библиотечной ассоциации (РБА), проходивший при поддержке Министерства культуры Российской Федерации и Администрации Владимирской области с 12 по 18 мая 2018 г. в Библиотечной столице России 2018 года - Владимире, а также в Суздале, Гороховце, поселках Боголюбово и Первомайском Владимирской области, с успехом сочетал в себе некоторые новации и традиционные, уже привычные черты прошедших конгрессов. Участниками этого масштабного события стали более 1250 специалистов из 62 регионов Российской Федерации, а также США, Германии и Румынии.

Тема Конгресса - «Опираясь на прошлое, строим будущее. Роль культурного наследия в пре-

\section{Ирина Александровна}

Трушина,

Российская библиотечная ассоциация, исполнительный директор

Садовая ул., д. 18,

Санкт-Петербург, 191069, Россия

кандидат педагогических наук

E-mail: trushina@nlr.ru

Виктория Владиславовна

Мещерякова,

Российская библиотечная ассоциация,

главный редактор сайта

Садовая ул., д. 18,

Санкт-Петербург, 191069, Россия

E-mail:pr@rba.ru 
образовании библиотечного дела России» - была продиктована отчасти уникальностью культурноисторического места, отчасти - вызовами времени: заявленной стратегической целью стала разработка Концепции развития библиотечного дела в Российской Федерации. Открытое обсуждение подготовки этого документа, проведенное 16 мая, стало одним из важнейших мероприятий Конгресса. Концепция готовится по инициативе президента РБА, директора Государственной публичной исторической библиотеки России М.Д. Афанасьева, который считает ее подготовку, с четко сформулированной миссией современной библиотеки, важнейшей [1, с. 476]. Первые проекты ее структуры и содержания обсуждались на заседаниях Правления РБА (заочных - до Конгресса и очных - во Владимире). По мнению М.Д. Афанасьева, в современных условиях создаваемая по инициативе РБА Концепция имеет несколько целей:

- дать представление о социальной значимости библиотечной отрасли органам власти;

- представить убедительную картину возможного динамического развития библиотек для решения социальных задач, стоящих перед страной (миссия и роль библиотек);

- продемонстрировать ясное представление профессионального сообщества о целях и средствах их достижения (модели библиотек и эффект от результатов преобразований);
- представить модели поддержки со стороны государства, которые обеспечат реализацию поставленных целей в среднесрочной перспективе (программа деятельности до 2025 г.).

Как отметил в итоговом докладе на заключительном пленарном заседании 17 мая М.Д. Афанасьев, обсуждение было конструктивным, участники дискуссии сошлись на том, что адресатом документа должны быть органы власти, а предварять появление Концепции мог бы Манифест библиотечного дела. Кроме того, концепции развития библиотек различных типов (вузовских, научных, библиотек субъектов РФ и др.) обсуждались на заседаниях секций РБА, что является ценным вкладом в разработку общей концепции. На Конференции РБА было принято Руководство по краеведческой деятельности общедоступных (публичных) библиотек РФ. Оно было разработано Секцией «Краеведение в современных библиотеках» РБА (председатель Н.М. Балацкая) с целью упорядочения краеведческой деятельности публичных библиотек, закрепления сложившихся в них эффективных форм и методов и отражения новых возможностей. Текст Руководства опубликован на сайте РБА [2].

Не менее важным событием Конгресса стало утверждение Правлением РБА Положения о Совете по профессиональным квалификациям в области библиотечно-информационной деятельности,

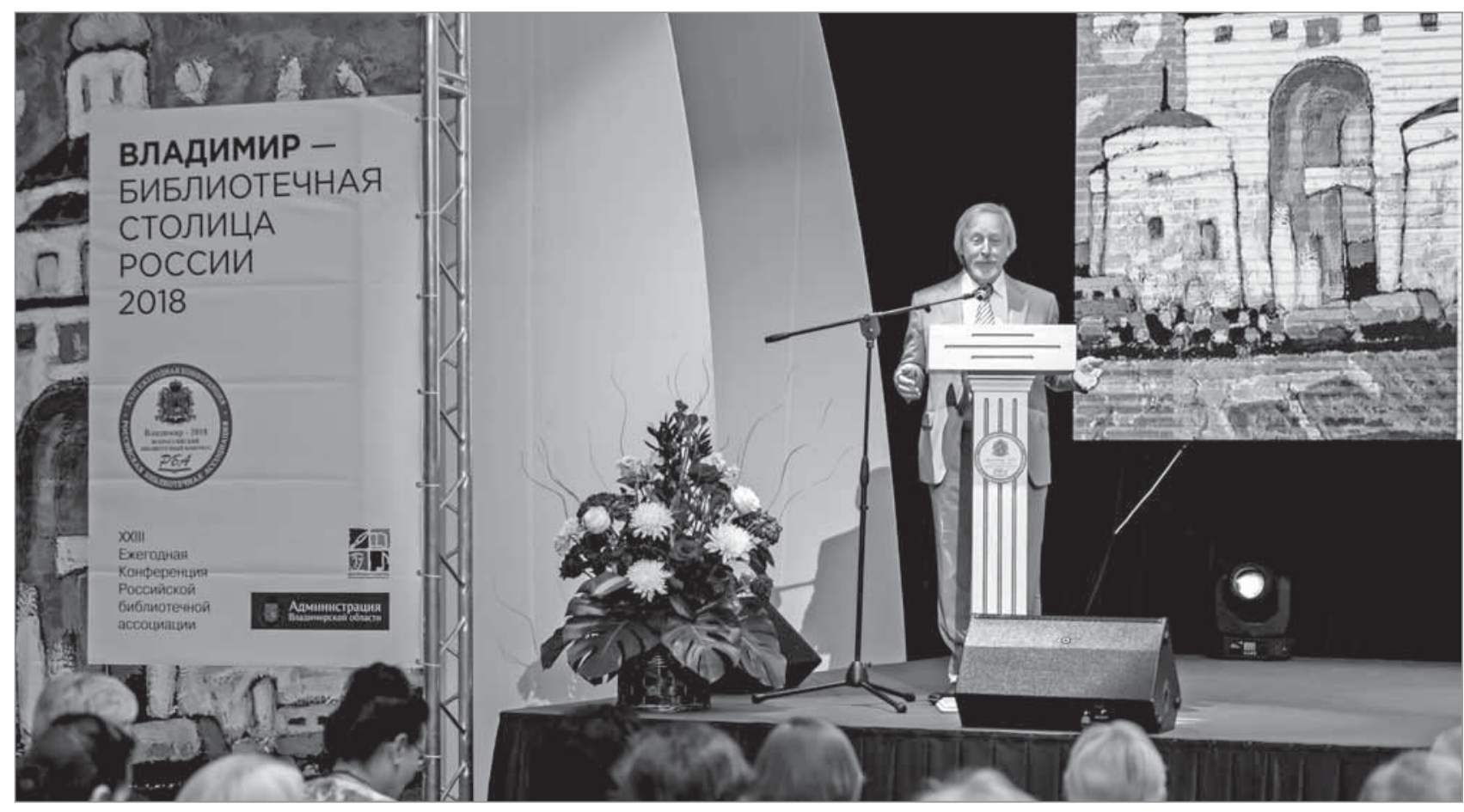

Президент РБА М.Д. Афанасьев выступает с докладол на пленарнол заседании Всероссийского библиотечного конгресса в Суздале 
подготовленного в соответствии с Федеральным законом «О независимой оценке квалификации» от 03.07.2016 г. № 238-ФЗ членом Правления РБА, профессором Московского государственного института культуры Т.Я. Кузнецовой. Проект Положения был обсужден и одобрен на заседании Секции библиотечной профессии, кадров и непрерывного образования РБА (председатель Е.Б. Артемьева). Функции Совета:

- разработка и актуализация профессиональных стандартов и квалификационных требований;

- проведение экспертизы федеральных государственных образовательных стандартов профессионального образования;

- организация профессионально-общественной аккредитации основных профессиональных образовательных программ;

- организация независимой оценки квалификации работников и др.

Профессиональная программа Конгресса, которая началась еще до его официального открытия, включала два однодневных пленарных заседания; два предсессионных заседания: Школа комплектатора и Школа библиотечного блогера; два заседания Правления РБА; 37 заседаний секций и круглых столов РБА по направлениям деятельности и по видам библиотек; 14 совместных заседаний секций и круглых столов; 9 специальных мероприятий, включая проведенную впервые Школу реставратора; профессиональный тур. В 19-й раз в рамках Конгресса состоялась выставка издательской продукции, новых информационных технологий, товаров и услуг, ко- торая в 2018 г. была организована в партнерстве с региональным книжным фестивалем «Бу!Фест» под общим названием «Библио-Бу!Фест». Профессиональную программу дополняли культурные мероприятия, в том числе встречи с почетными гостями Конгресса: общественным деятелем, президентом Фонда Солженицына Н.Д. Солженицыной и поэтом, членом Общественной палаты РФ А.Д. Дементьевым.

Торжественное открытие и пленарное заседание Конгресса состоялись 14 мая в Суздале [3; 4]. Открыли Конгресс губернатор Владимирской области С.Ю. Орлова и президент РБА М.Д. Афанасьев. С.Ю. Орлова представила доклад о ключевых достижениях в сфере культуры Владимирской области. Она отметила, что столица - слово, которое можно часто услышать на Владимиро-Суздальской земле: здесь находятся города, в которых в разное время вершились судьбы страны, начиналась российская государственность, закладывались основы великой русской культуры, хранятся традиции русского народа. Но Библиотечная столица - особенно почетное звание, которое свидетельствует о признании достижений и заслуг библиотекарей. По словам С.Ю. Орловой, Владимирская область является одним из лидирующих в России регионов по развитию сферы культуры, а библиотеки являются первыми форпостами культуры. Она подробно рассказала о ключевых событиях и инициативах, уделив особое внимание проектам библиотек: «Расти с книгой, малыш», «Классно о классиках», «Читаем Солоухина вместе», «Ночь перед экзаменом» и др.

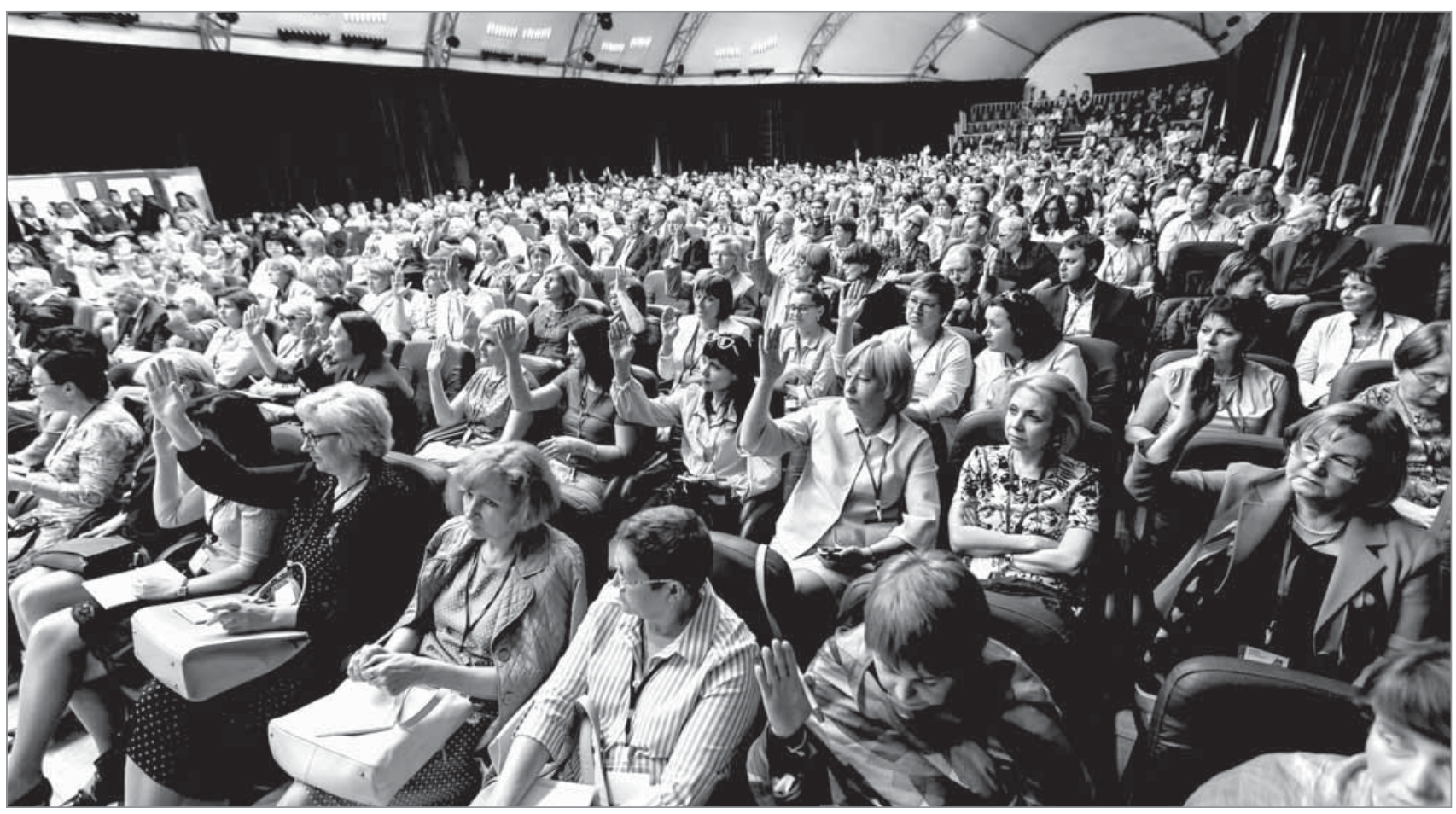

Участники пленарного заседания Всероссийского библиотечного конгресса в Суздале 
В регионе работают 460 библиотек, в их числе 3 областные, 16 межпоселенческих, 25 детских, 341 библиотека в сельской местности. В 2017 г. жители региона посетили библиотеки 5,4 млн раз (в 2016 г. - 5,2 млн), в среднем один житель области посещал библиотеку 4 раза в год. Губернатор упомянула о модернизированной Боголюбовской поселковой библиотеке и поприветствовала присутствующую в зале заведующую библиотекой, победителя I Всероссийского конкурса «Библиотекарь года» О.А. Андон.

«Книга - основа нашей жизни, и сегодняшний наш форум свидетельствует об этом. Мы родом из читающей страны и должны создавать такие условия, чтобы повзрослевшие дети с благодарностью вспоминали своих библиотекарей», подытожила Светлана Юрьевна, поблагодарив за сотрудничество М.Д. Афанасьева, почетных гостей Конгресса, всех библиотекарей региона «людей уникальных, креативных, неравнодушных и любящих свою работу» [5].

Участников Конгресса поздравили с началом работы заместитель председателя Комитета Совета Федерации по науке, образованию и культуре C.Е. Рыбаков, который зачитал приветствие от председателя Совета Федерации Федерального Собрания РФ В.И. Матвиенко; вице-президент Российской академии образования В.В. Лаптев; президент Российского книжного союза С.В. Степашин; профессор, руководитель проектов Рутгерского университета (Нью Джерси, США), президент (2000-2001 гг.) Американской библиотечной ассоциации Н. Краник. В адрес участников Конгресса поступило также приветствие от министра культуры РФ В.Р. Мединского.

М.Д. Афанасьев представил на пленарном заседании доклад о ключевых направлениях деятельности Ассоциации в течение года. Он обратил внимание, что деятельность РБА давно выходит за круг членов Ассоциации: например, Всероссийский конкурс «Библиотекарь года» или Всероссийский форум публичных библиотек традиционно собирают наиболее активную часть сообщества. По его словам, «РБА объединяет библиотекарей как представителей единого профессионального сообщества. Наша Ассоциация думает о профессиональных проблемах, отвечает за них во всероссийском масштабе. Мы работаем на будущее ради сохранения и развития нашей профессиональной среды» [6]. М.Д. Афанасьев затронул основные проблемы отрасли: изменение нормативов обеспеченности населения библиотеками, недостаточное комплектование фондов, необходимость развития профессионального библиотечного образования и др. Президент РБА анонсировал Всероссийскую акцию «Я - РБА», которая инициирована для поощрения самых активных специалистов библиотек России. Он также объявил о проведении Всероссийского конкурса «Библиотекарь 2018 года», учрежденного Министерством культуры РФ и про- водимого Российской национальной библиотекой (РНБ) и Санкт-Петербургским государственным институтом культуры (СПбГИК) при поддержке РБА. Благодарность за профессиональную активность была вручена заведующей отделом обслуживания Великолукской центральной городской библиотеки им. М.И. Семевского, победителю в основной номинации Всероссийского конкурса «Библиотекарь 2017 года» А.С. Фроловой.

В качестве почетных гостей на пленарном заседании выступили А.Д. Дементьев, который говорил о важнейшей роли книги в жизни человека, и Н.Д. Солженицына, подробно осветившая роль чтения и книг на различных этапах жизни Александра Исаевича Солженицына, а также писатель, общественный деятель С.А. Шаргунов с докладом «Защита культуры и судьба страны» о необходимости искать на законодательном уровне механизмы для постоянной поддержки и защиты библиотек, поскольку «библиотека - это штаб культуры» [6].

15 и 16 мая работа Конгресса продолжалась на заседаниях секций и круглых столов РБА, специальных мероприятиях. Специалисты обсуждали традиционно широкий спектр вопросов: от роли библиотечного сообщества в подготовке нового федерального закона «О культуре» и перспектив международного сотрудничества до ключевых достижений и важнейших направлений деятельности библиотек различных типов.

Отчеты заседаний секций публикуются на сайте РБА (www.rba.ru). В рамках данной статьи обозначим лишь некоторые тенденции и события.

Вопросы библиотечной политики и законодательства обсуждались сразу на нескольких площадках. Обзорный доклад о новом в государственной библиотечной политике сделал председатель Секции по библиотечной политике и законодательству, заместитель генерального директора РНБ по научной работе В.Р. Фирсов. Предметом дискуссии на заседании стали вопросы о разрабатывающемся по поручению Президента РФ В.В. Путина Федеральном законе «О культуре». Это поручение было дано Администрации Президента РФ и Совету при Президенте РФ по культуре и искусству по итогам заседания Совета по культуре и искусству при Президенте РФ 21 декабря 2017 года. Дискуссии участников заседания Секции по библиотечной политике были сосредоточены на вопросах представления библиотек в данном законе. В докладе советника дирекции Российской государственной библиотеки (РГБ) Н.А. Сахарова прозвучало предложение создать рабочую группу при РБА на этапе публикации первого проекта будущего закона для формирования консолидированной позиции библиотечного сообщества и внесения предложений в законопроект. Он высказал также предположение, что многие из положений действующих «Основ государственной культурной политики», прямо или опосредованно 
касающихся библиотек и библиотечной работы, найдут свое воплощение в проекте федерального закона «О культуре».

Перспективы развития Национальной электронной библиотеки (НЭБ), ее правовая основа и представление интересов библиотек на новом этапе развития в свете Указания Президента РФ В.В. Путина от 17 февраля 2018 г. № Пр-294, где предусматривается обеспечение включения в НЭБ электронных копий $100 \%$ российских изданий на правах обязательного экземпляра [7], а также предложения по реформированию системы обязательного экземпляра в России обсуждались на заседании Секции по библиотечной политике и законодательству РБА, Секции «Электронные ресурсы и информационно-библиотечное обслуживание» (председатель Е.Д. ЖКабко), совместном заседании Секции по формированию библиотечных фондов (председатель И.В. Эйдемиллер) и Секции по издательской и книгораспространительской деятельности (председатель Е.В. Никонорова) при поддержке Российского книжного союза. По итогам заседания секций с участием представителей РГБ, РНБ, Российской книжной палаты, центральных библиотек субъектов РФ было принято несколько решений: ввести представителя РБА в рабочую группу по НЭБ при Межведомственном совете по НЭБ, организовать рабочую группу в РБА по НЭБ, проработать процедуру включения в НЭБ обязательного экземпляра электронных копий печатного издания и др.

По результатам работы Секции музыкальных библиотек (председатель А.А. Семенюк) было высказано пожелание в адрес руководства РБА: при работе над новой редакцией закона «О культуре» учитывать специфику музыкального искусства и найти способы вывода музыкальных библиотек из правового поля закона «Об авторском праве и смежных правах» (или смягчения условий его исполнения). Второе предложение было высказано в адрес НЭБ в поддержку ее главной миссии общедоступности, т. е. возможности музыкантов и музыкальных исследователей из любого места в России не только иметь свободный доступ к полнотекстовым музыкальным коллекциям НЭБ (из дома и из читального зала любой библиотеки, даже не являющейся участницей НЭБ), но и активно заниматься формированием базы данных авторских обучающих программ и наглядных мастер-классов ведущих преподавателей, исполнителей.

Об изменениях в федеральных законах «Об обязательном экземпляре документов», «О библиотечном деле», «О противодействии экстремистской деятельности», «О контрактной системе в сфере закупок товаров, работ, услуг для обеспечения государственных и муниципальных нужд” говорили на обучающем мероприятии «Школа комплектатора: новое в нормативных документах по формированию библиотечных фондов» .
Государственная программа поддержки детского и юношеского чтения обсуждалась на совместном заседании Секции публичных библиотек (председатель С.Ф. Бартова), Секции детских библиотек (председатель Н.С. Абрамова), Секции школьных библиотек (председатель В.Н. Тарасенко), Секции по чтению (председатель В.В. Ялышева). Как было отмечено, основная проблема реализации такого рода программ состоит в налаживании межведомственного сотрудничества институтов инфраструктуры детского чтения (школьные, детские, публичные библиотеки, книгоиздательства, учреждения образования и культуры). На заседании состоялась презентация проекта Методических рекомендаций по подготовке региональных программ поддержки детского и юношеского чтения, разработанных авторским коллективом Российской государственной детской библиотеки.

Секция центральных библиотек субъектов РФ (председатель С.С. Дедюля), Секция по библиотечной политике и законодательству (председатель В.Р. Фирсов), Секция публичных библиотек (председатель С.Ф. Бартова), Секция «Библиотечные общества и ассоциации» (председатель С.А. Басов) провели совместное заседание «Трансформации библиотечной сети в регионах России». Заседание открыл М.Д. Афанасьев, который подчеркнул значимость обсуждения вопросов состояния библиотечной сети страны и мониторинга изменений, отметил важную роль центральных библиотек субъектов РФ в упорядочении региональных библиотечных сетей, работе совместно с РБА над нормативами федерального и регионального уровней. После докладов заседание продолжилось открытой дискуссией «Общедоступные библиотеки в условиях оптимизации: опыт сохранения и развития», на которой обсуждались вопросы разработки и применения в регионах нормативов обеспеченности населения общедоступными библиотеками. Предварил обсуждение доклад С.А. Басова «O сохранении и развитии общедоступных библиотек: федеральный и региональный подходы». По итогам обсуждения на сайте РБА от имени Секции центральных библиотек субъектов Российской Федерации и Секции «Библиотечные общества и ассоциации" опубликована Резолюция, в которой подчеркивается необходимость включения данных о деятельности общедоступных библиотек в официальные публикации Министерства культуры РФ. Также указывается, что в соответствии с Указом Президента РФ от 07.05.2018 г. № 204 «О национальных целях и стратегических задачах развития Российской Федерации на период до 2024 года" (в части создания (реконструкции) культурнодосуговых организаций клубного типа на территориях сельских поселений, развития муниципальных библиотек) [8] общедоступные 
(муниципальные) библиотеки на селе и в малых городах следует включить в программы государственной поддержки ремонта, модернизации и нового строительства, наряду с декларированной Министерством культуры РФ на 2018 г. программой поддержки домов культуры. Эта программа предполагает:

- вложение финансовых средств на 2019 г. в объеме более шести млрд руб.;

- развитие эффективных форм общественно-государственного партнерства Министерства культуры РФ с библиотечным сообществом;

- модернизацию государственной статистики, которая в сводных данных не учитывает деятельность библиотек (библиотечных подразделений) в составе культурно-досуговых и иных учреждений, что приводит к искажению масштабов деятельности библиотечной отрасли, уменьшает объем библиотечных услуг населению более чем на $15 \%$ в масштабе страны.

В Резолюции Правлению РБА рекомендуется добиваться: отмены Распоряжения Минкультуры РФ от 02.08.2017 г. № 965, как противоречащего Распоряжению Правительства РФ от 22.12.2017 г. № 2905-р, которым все федеральные сетевые нормативы были отменены; выполнения Распоряжения Правительства РФ от 22.12.2017 г. №2905-р, в части разработки и утверждения новых нормативов обеспеченности населения общедоступными библиотеками на основе предложений Правления РБА, переданных президентом РБА М.Д. Афанасьевым в Минкультуры РФ в феврале 2018 года. Рекомендуется рассмотреть вопрос о подготовке и принятии Базовых нормативов обеспеченности населения общедоступными библиотеками в качестве нормативно-рекомендательного акта РБА; принять меры к возобновлению федеральной субсидии регионам России на цели комплектования муниципальных библиотек в объеме не менее 300 млн руб. в год» [9]. Центральным библиотекам субъектов РФ, библиотечным обществам и ассоциациям рекомендуется «усилить работу по подготовке и представлению органам власти субъектов РФ проектов региональных нормативов обеспеченности населения общедоступными библиотеками с учетом местных особенностей, нормативов, направленных на восстановление “действительной шаговой доступности” в первичном звене библиотечной сети, на что указал Президент РФ в Послании Федеральному собранию 1 марта 2018 года применительно к здравоохранению и другим отраслям социально-культурной сферы [9].

Еще одним документом, опубликованным по итогам мероприятий Конгресса, стала «Суздальская декларация» [10], принятая участниками 2-й рабочей встречи Российско-американского диалога «Библиотеки и общество в XXI веке», проведенной по инициативе Всероссийской государственной библиотеки иностранной литературы им. М.И. Рудомино (ВГБИЛ им. М.И. Рудомино) в рамках работы Секции по международному сотрудничеству РБА (председатель В.В. Дуда). Участники встречи, сравнивая опыт трансформации американских и российских библиотек в центры общественной жизни, обсудили видение меняющейся роли библиотек, их способность выявлять потребности сообщества и отвечать его нуждам, содействовать реализации Целей в области устойчивого развития ООН [11]. В «Суздальской декларации» отражены миссия, цели и задачи российско-американского библиотечного диалога. Например, говорится, что «диалог утверждает роль библиотек как активных участников жизни местных сообществ»; в качестве миссии декларируется «свободный обмен идеями и опытом развития (трансформации) библиотек в целях создания более сплоченного и открытого к пониманию друг друга мирового сообщества» [10].

Итоговая резолюция была принята после заседания Секции по сохранности библиотечных фондов РБА (председатель Е.М. Лоцманова). В ней содержится обращение к профессиональному сообществу для поддержки Программы «Пополнение Российского страхового фонда документов библиотек» как одной из важнейших составляющих библиотечной деятельности по сохранению национального культурного наследия, в условиях прекращения в 2017 г. государственного финансирования работы по созданию страхового фонда документов библиотек в рамках Федеральной целевой программы «Культура России (20122018 годы)»: «Остановка в середине пути обесценивает все предыдущие материальные вложения и сводит на нет кропотливый труд нескольких десятилетий по выстраиванию общероссийской системы сохранения богатейшего книжного наследия нашей страны» [12]. Примечательно, что на Конгрессе впервые была проведена Школа реставратора по инициативе ВГБИЛ им. М.И. Рудомино и при поддержке Секции по сохранности библиотечных фондов РБА.

Одно из специальных мероприятий, которое было проведено под эгидой Секции библиотечной профессии, кадров и непрерывного образования и вызвало большой отклик, посвящалось 100-летию СПбГИК [13]. Тема встречи: «Библиотечное образование сегодня: уничтожить нельзя сохранить. Где поставить запятую?». Модераторами дискуссии выступили ректор СПбГИК А.С. Тургаев и директор Российской государственной библиотеки для молодежи, вице-президент РБА И.Б. Михнова. В ходе дискуссии обсуждались вопросы:

- какой молодой специалист - выпускник библиотечной школы - нужен библиотекам сегодня;

- в чем уникальность профессионального библиотечного образования;

- каким образом практики готовы включиться в подготовку специалистов; 
- какой абитуриент приходит учиться на библиотекаря.

В мероприятии приняли участие руководители и ведущие специалисты федеральных и центральных региональных библиотек, вузов культуры и других учреждений, заинтересованных в подготовке библиотечных кадров [14].

Впервые на Конгрессе состоялся круглый стол библиотек пенитенциарных учреждений (тюремных библиотек), которые, надеемся, войдут в профессиональное библиотечное сообщество для обмена опытом, идеями, новациями.

Подробнее с информацией о заседаниях Конгресса можно ознакомиться на сайте Российской библиотечной ассоциации в разделах секций РБА [15] и общем итоговом обзоре по Конгрессу [16].

17 мая 2018 г. во Владимире в Областном дворце культуры и искусства состоялось итоговое пленарное заседание Конгресса, которое вели заместитель директора Департамента науки и образования Министерства культуры РФ Е.О. Китаева; президент РБА М.Д. Афанасьев; исполнительный директор РБА И.А. Трушина и директор Владимирской областной универсальной научной библиотеки Т.В. Брагина.

По словам М.Д. Афанасьева, Ежегодная конференция РБА во Владимире может считаться рекордной по докладам (около 600) и продолжительности (6 рабочих дней). Он обратил внимание, что число докладов и площадок год от года постоянно увеличивается: библиотечное сообщество считает необходимым ключевые проблемы отрасли обсуждать на крупных форумах - это признак высокого авторитета Конгресса и РБА. М.Д. Афанасьев также подчеркнул, что повестка заседаний - заслуга не Правления РБА, а руководителей секций. По его мнению, тема Конгресса «Опираясь на прошлое, строим будущее. Роль культурного наследия в преобразовании библиотечного дела России» себя оправдала: «Это была попытка рассуждать о том, как богатое наследие наших фондов соотносится с динамичным развитием цифровой эпохи, и какая у нас должна быть система приоритетов» [17].

С завершением Конгресса участников поздравили заместитель губернатора Владимирской области М.Ю. Колков, заместитель председателя Законодательного собрания Владимирской области В.Ю. Картухин, председатель Общественной палаты Владимирской области Н.В. Юдина. После выступлений они вручили специалистам библиотек Владимирской области почетные грамоты и благодарности Администрации, Законодательного собрания и Общественной палаты региона. По словам М.Ю. Колкова, Всероссийский библиотечный конгресс среди культурных событий области стоит особняком: не только потому, что в нем принимали участие настоящие «полпреды культуры» - библиотекари, но также благодаря впечатляюще обширной программе. По его словам, «при должной поддержке на муниципальном и региональном уровне библиотеки становятся многопрофильными мультикультурными площадками и опорными площадками социальной политики, а книга остается надежным спутником человека» [17].

В заключительной части итогового пленарного заседания Конгресса состоялась торжественная церемония «Посвящение в профессию» (для молодых специалистов области), были вручены медали РБА «За вклад в развитие библиотек», почетные грамоты и благодарности РБА; объявлены итоги Всероссийского конкурса «Литература многонациональной России и зарубежья» .

Звание «Библиотечная столица России 2019 года» присвоено Туле. От имени принимающего региона символ «Библиотечной столицы» директору Тульской областной универсальной научной библиотеки Т.В. Тихоненковой передала исполняющая обязанности директора Департамента культуры Владимирской области В.С. Зиннатуллина.

Работа Всероссийского библиотечного конгресса традиционно освещалась в средствах массовой информации [18], был подготовлен итоговый видеоролик о Всероссийском библиотечном конгрессе [16]. Материалы и доклады Конгресса готовятся к публикации в Информационном бюллетене РБА.

\section{Список источников}

1. Мещерякова В.В. РБА на пороге изменений: выборы нового президента, ожидания, прогнозы (итоги работы Всероссийского библиотечного конгресса в Красноярске) // Библиотековедение. 2017. Т. 66, № 4. C. 473-477. DOI: 10.25281/0869-608X-201766-4-473-477.

2. Опубликован нормативно-рекомендательный документ РБА «Руководство по краеведческой деятельности общедоступных (публичных) библиотек РФ» [Электронный ресурс] // Российская библиотечная ассоциация : офиц. сайт. URL: http://www. rba.ru/news/news_1317.html (дата обращения: 28.06.2018).

3. Торжественное открытие Всероссийского библиотечного конгресса [Видеозапись]. URL: https:// www.youtube.com/watch?v=CV6BA1wWG8g (дата обращения: 28.06.2018).

4. Пленарное заседание Всероссийского библиотечного конгресса 15 мая 2018 г. [Видеозапись]. URL: https://www.youtube.com/watch?v=FjWVCy2x0Wc (дата обращения: 28.06.2018).

5. Всероссийский библиотечный конгресс - 2018 приступил к работе в Суздале [Электронный ресурс] // Российская библиотечная ассоциация : офиц. сайт. URL: http://www.rba.ru/news/news_1245.html (дата обращения: 28.06.2018).

6. Итоговый обзор. Всероссийский библиотечный конгресс: XXIII Ежегодная конференция Российской библиотечной ассоциации [Электронный ресурс] // Российская библиотечная ассоциация : офиц. сайт. URL: http://www.rba.ru/activities/conference/ 
conf-2018/about/itogovyy-obzor/ (дата обращения: 28.06.2018).

7. Национальные проекты: современное состояние и перспективы развития : материалы пленарной дискуссии [Электронный ресурс] // VIII Всероссийская научно-практическая конференция «Фонды библиотек в цифровую эпоху: традиционные и электронные ресурсы, комплектование, использование», 26-30 марта 2018 г., Санкт-Петербург : материалы. URL: http://nlr.ru/tus/20180326/program.html (дата обращения: 28.06.2018).

8. Указ Президента Российской Федерации от 07.05.2018 г. № 204 «О национальных целях и стратегических задачах развития Российской Федерации на период до 2024 года [Электронный ресурс] // Президент России : офиц. сайт. URL: http://www. kremlin.ru/acts/bank/43027/page/1 (дата обращения: 28.06.2018).

9. Приглашаем ознакомиться с Резолюцией Секции центральных библиотек субъектов РФ и Секции «Библиотечные общества и ассоциации» по итогам заседаний на Конгрессе во Владимире [Электронный ресурс] // Российская библиотечная ассоциация : офиц. сайт. URL: http://www.rba.ru/news/ news_1364.html (дата обращения: 28.06.2018).

10. Суздальская декларация [Электронный ресурс] // Российская библиотечная ассоциация : офиц. сайт. URL: http://www.rba.ru/activities/conference/conf2018/about/zasedaniya/meetings_518.html (дата обращения: 28.06.2018).

11. Цели в области устойчивого развития [Электронный ресурс] // Организация объединенных наций : офиц. сайт. URL: https://www. un.org/sustainabledevelopment/ru/sustainabledevelopment-goals / (дата обращения: 28.06.2018).

12. Заседание Секции 06. Секция по сохранности библиотечных фондов, XXIII Ежегодная сессия Конференции РБА, Владимир, 12.05.2018-18.05.2018
[Электронный ресурс] // Российская библиотечная ассоциация : офиц. сайт. URL: http://www.rba.ru/ activities/sections/annual/annual_522.html (дата обращения: 28.06.2018).

13. Библиотечное образование сегодня: уничтожить нельзя сохранить. Где поставить запятую? [Видеозапись]. URL: https://www.youtube. com/watch?v=mtwuAf-dMoU (дата обращения: 28.06.2018).

14. Заседание Секции 09/10. Секция библиотечной профессии, кадров и непрерывного образования, XXIII Ежегодная сессия Конференции РБА, Владимир, 12.05.2018-18.05.2018 [Электронный ресурс] // Российская библиотечная ассоциация : офиц. сайт. URL: http://www.rba.ru/activities/ sections/annual/annual_527.html (дата обращения: 28.06.2018).

15. Секции и круглыестолыРБА[Электронный ресурс]// Российская библиотечная ассоциация : офиц. сайт. URL: http://www.rba.ru/activities/sections/ (дата обращения: 28.06.2018).

16. Владимир - библиотечная столица России 2018 года [Электронный ресурс]// Российская библиотечная ассоциация : офиц. сайт. URL: http://www.rba.ru/ activities/conference/conf-2018/index/ (дата обращения: 28.06.2018).

17. Всероссийский библиотечный конгресс завершился во Владимире [Электронный ресурс] // Российская библиотечная ассоциация : офиц. сайт. URL: http:// www.rba.ru/news/news_1259.html (дата обращения: 28.06.2018).

18. СМИ о Конгрессе [Электронный ресурс] // Российская библиотечная ассоциация : офиц. сайт. URL: http://www.rba.ru/activities/conference/conf-2018/ about/media/smi-o-kongresse / (дата обращения: 28.06.2018).

Фото В. Чучадеева

\title{
All-Russian Library Congress 2018: On the Way to Creation of the Librarianship Development Concept
}

\author{
Irina A. Trushina*, Victoria V. Meshcheryakova**, \\ Russian Library Association, 18 Sadovaya Str., St. Petersburg, 191069, Russia \\ E-mail:*trushina@nlr.ru,** pr@rba.ru
}

Abstract. The article presents an analytical review of the All-Russian Library Congress, held in Vladimir -
the Library Capital of Russia 2018 - on 12-18 May 2018. The Congress was devoted to the theme "Ba-
sing on the Past, We Build the Future. The Role of Cultural Heritage in Transforming the Librarianship in
Russia". The Congress held an open Discussion on the concept of librarianship development in the Russian
Federation; it adopted the Guidelines on local lore activities for public libraries of the Russian Federation
and approved the Regulations on the Council for Professional Qualifications in the Field of Library and
Information Activities, planned for creation under the Russian Library Association. The Congress worked 
in various formats: pre-session events, plenary sessions, section meetings by library types and activity areas, and special events. The 19th Exhibition of Publishing Products, New Information Technologies, Goods and Services complemented the Congress. The Congress determined Tula to be the Library Capital of Russia 2019.

Key words: Russian Library Association, RLA, All-Russian Library Congress, RLA Annual Conference, Library Capital of Russia, Concept of Librarianship Development, State Library Policy, Libraries of the Vladimir Region, Librarian of the Year, Library Education.

Citation: Trushina I.A., Meshcheryakova V.V. All-Russian Library Congress - 2018: On the Way to Creation of the Librarianship Development Concept, Bibliotekovedenie [Library and Information Science (Russia)], 2018, vol. 67, no. 3, pp. 247-256. DOI: 10.25281/0869-608X-2018-67-3-247-256.

\section{References}

1. Meshcheryakova V.V. The Russian Library Association on the Threshold of Change: Election of the New President, Expectations and Forecasts (Results of the All-Russian Library Congress in Krasnoyarsk), Bibliotekovedenie [Library and Information Science (Russia)], 2017, vol. 66 , no. 4, pp. 473-477 (in Russ.). DOI: 10.25281/0869-608Kh-2017-66-4-473-477.

2. Opublikovan normativno-rekomendatel'nyi dokument RBA “Rukovodstvo po kraevedcheskoi deyatel'nosti obshchedostupnykh (publichnykh) bibliotek RF" [The Russian Library Association's Regulatory and Advisory Document “Guidelines on Regional Activities for Public Libraries of the Russian Federation" Is Published], Rossiiskaya bibliotechnaya assotsiatsiya: ofits. sait [Russian Library Association: official website]. Available at: http://www.rba.ru/news/ news_1317.html (accessed 28.06.2018) (in Russ.).

3. Torzhestvennoe otkrytie Vserossiiskogo bibliotechnogo kongressa [Grand Opening of the All-Russian Library Congress]. Available at: https://www.youtube.com/ watch? $\mathrm{v}=\mathrm{CV} 6 \mathrm{BA} 1 \mathrm{wWG} 8 \mathrm{~g}$ (accessed 28.06.2018).

4. Plenarnoe zasedanie Vserossiiskogo bibliotechnogo kongressa 15 maya 2018 goda [A Plenary Session of the All-Russian Library Congress on May 15, 2018]. Available at: https://www.youtube.com/ watch?v=FjWVCy2x0Wc (accessed 28.06.2018).

5. The All-Russian Library Congress - 2018 Started its Work in Suzdal, Rossiiskaya bibliotechnaya assotsiatsiya: ofits. sait [Russian Library Association: official website]. Available at: http://www.rba.ru/news/ news_1245.html (accessed 28.06.2018) (in Russ.).

6. Final Review. All-Russian Library Congress: The 23d Annual Conference of the Russian Library Association, Rossiiskaya bibliotechnaya assotsiatsiya: ofits. sait [Russian Library Association: official website]. Available at: http://www.rba.ru/activities/ conference/conf-2018/about/itogovyy-obzor/ (accessed 28.06.2018) (in Russ.).

7. National Projects: Current State and Development Prospects: Plenary Discussion Proceedings, VIII Vserossiiskaya nauchno-prakticheskaya konferentsiya "Fondy bibliotek $v$ tsifrovuyu epokhu: traditsionnye $i$ elektronnye resursy, komplektovanie, ispol'zovanie”, 26-30 marta 2018 g., Sankt-Peterburg: materialy [Proceedings of the 8th All-Russian Scientific-Practical Conference "Library Collections in the Digital Age: Traditional and Electronic Resources, Acquisition, and Use" (March 26-30, 2018, St. Petersburg)].
Available at: http://nlr.ru/tus/20180326/program. html (accessed 28.06.2018) (in Russ.).

8. The Decree of the President of the Russian Federation of 07.05.2018 № 204 “On the National Goals and Strategic Objectives of the Russian Federation Development for the Period up to 2024, Prezident Rossii: ofits. sait [President of Russia: official website]. Available at: http://www.kremlin.ru/acts/bank/43027/page/1 (accessed 28.06.2018) (in Russ.).

9. Get Acquainted with the Resolution of the Section of Central Libraries of the Russian Federation Constituent Entities and the Section of "Library Communities and Associations" on the Results of the Meetings at the Congress in Vladimir, Rossiiskaya bibliotechnaya assotsiatsiya: ofits. sait [Russian Library Association: official website]. Available at: http://www.rba. $\mathrm{ru} /$ news/news_1364.html (accessed 28.06.2018) (in Russ.).

10. Suzdal Declaration, Rossiiskaya bibliotechnaya assotsiatsiya: ofits. sait [Russian Library Association: official website]. Available at: http://www.rba.ru/ activities/conference/conf-2018/about/zasedaniya/ meetings_518.html (accessed 28.06.2018) (in Russ.).

11. Sustainable Development Goals, United Nations: official website. Available at: https://www.un.org/sus tainabledevelopment/ (accessed 28.06.2018).

12. Meeting of Section 06. The Section for Preservation of Library Collections, The 23d Annual Session of the Conference of the Russian Library Association, Vladimir, 12.05.2018-18.05.2018, Rossiiskaya bibliotechnaya assotsiatsiya: ofits. sait [Russian Library Association: official website]. Available at: http:// www.rba.ru/activities/sections/annual/annual_522. html (accessed 28.06.2018) (in Russ.).

13. Bibliotechnoe obrazovanie segodnya: unichtozhit' nel'zya sokhranit'. Gde postavit' zapyatuyu? [Library Education Today: Should Be Destroyed or Saved?]. Available at: https://www.youtube.com/ watch? $\mathrm{v}=$ mtwuAf-dMoU (accessed 28.06.2018).

14. Meeting of Section 09/10. The Section of Library Profession, Staff and Continuing Education, The 23d Annual Session of the Conference of the Russian Library Association, Vladimir, 12.05.2018-18.05.2018, Rossiiskaya bibliotechnaya assotsiatsiya: ofits. sait [Russian Library Association: official website]. Available at: http://www.rba.ru/activities/sections/ annual/annual_527.html (accessed 28.06.2018) (in Russ.). 
15. Sections and Round Tables of the Russian Library Association, Rossiiskaya bibliotechnaya assotsiatsiya: ofits. sait [Russian Library Association: official website]. Available at: http://www.rba.ru/activities/ sections / (accessed 28.06.2018) (in Russ.).

16. Vladimir - The Library Capital of Russia 2018, Rossiiskaya bibliotechnaya assotsiatsiya: ofits. sait [Russian Library Association: official website]. Available at: http://www.rba.ru/activities/conference/conf2018/index/ (accessed 28.06.2018) (in Russ.).
17. The All-Russian Library Congress was closed in Vladimir, Rossiiskaya bibliotechnaya assotsiatsiya: ofits. sait [Russian Library Association: official website]. Available at: http://www.rba.ru/news/ news_1259.html (accessed 28.06.2018) (in Russ.).

18. Media about the Congress, Rossiiskaya bibliotechnaya assotsiatsiya: ofits. sait [Russian Library Association: official website]. Available at: http://www.rba.ru/ activities/conference/conf-2018/about/media/smio-kongresse/ (accessed 28.06.2018) (in Russ.).

\section{ПРАВИЛА ПРЕДОСТАВЛЕНИЯ СТАТЕЙ В журнал шБиблиотековедениеш}

ОБВЕМ СТАТЬИ

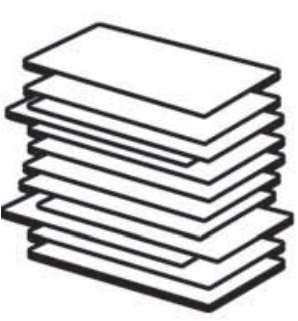

шрифт Times New

Roman, $12 \mathrm{pt}$, интерлиньяж 1,5

Реферат не менее 250 слов

\section{ИЛЛОстРАДИИ}

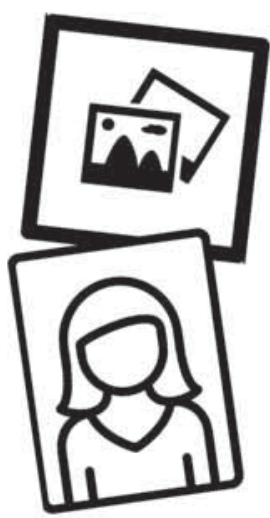

\section{0 dpi}

должны иметь

подрисуночные подписи,

быть адаптированы

для черно-белой

печати высокого

качества,

отдельными файлами

\section{TIFF/JPG}

фотография автора

обязательна
СВЕДЕНИЯ ОБ АВТОРЕ

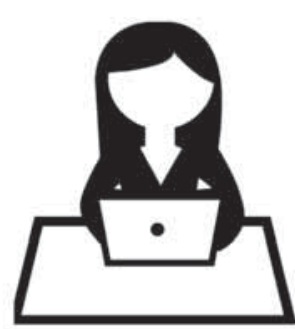

1 Имя, Отчество, Фамилия

2 место работы (учебы), должность

3 почтовый адрес

организации

4 ученая степень, ученое звание

5 e-mail

\section{СПИСОК ИСТОчНИКОВ}

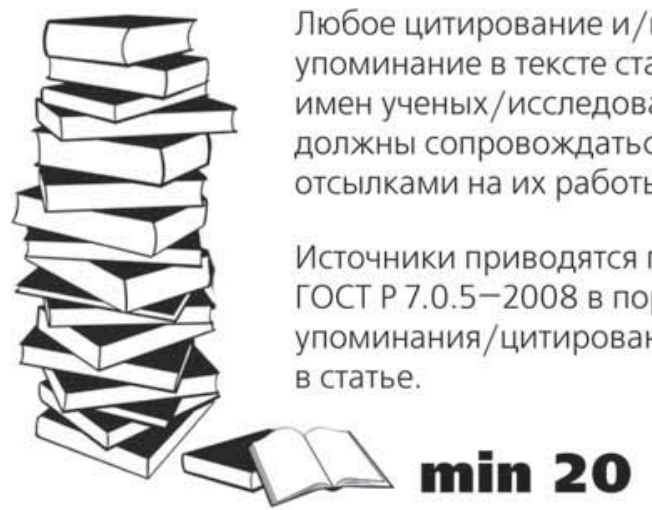

Редакция принимает только оригинальные, не публиковавшиеся ранее научные статьи. Правовые вопросы, связанные с публикацией в журнале, регулируются на основе подписанного Акцепта к Публичной оферте.

http://bibliotekovedenie.rsl.ru bupress@rsl.ru 